This item was submitted to Loughborough's Research Repository by the author.

Items in Figshare are protected by copyright, with all rights reserved, unless otherwise indicated.

\title{
Review and implementation of performance management models in construction engineering organizations
}

PLEASE CITE THE PUBLISHED VERSION

\section{PUBLISHER}

(C) Emerald Group Publishing Limited

\section{VERSION}

AM (Accepted Manuscript)

\section{LICENCE}

CC BY-NC-ND 4.0

\section{REPOSITORY RECORD}

Carrillo, Patricia M., Herbert S. Robinson, Chimay J. Anumba, and Ahmed M. Al-Ghassani. 2019. "Review and Implementation of Performance Management Models in Construction Engineering Organizations". figshare. https://hdl.handle.net/2134/4170. 
This item was submitted to Loughborough's Institutional Repository (https://dspace.lboro.ac.uk/) by the author and is made available under the following Creative Commons Licence conditions.

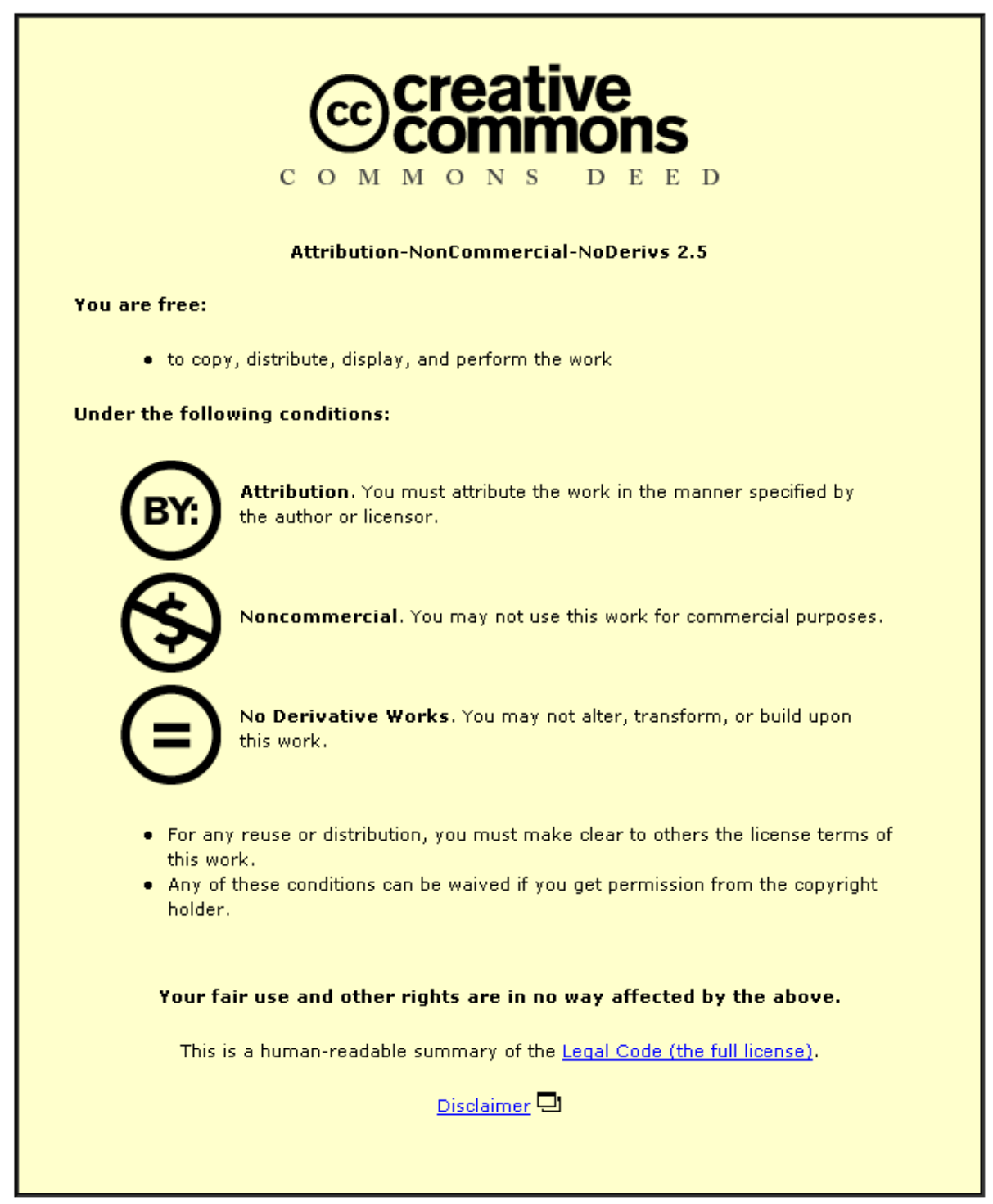

For the full text of this licence, please go to: http://creativecommons.org/licenses/by-nc-nd/2.5/ 


\title{
Review and Implementation of Performance Management Models in Construction Engineering Organisations
}

\author{
H.S. Robinson BSc (Hons), MIP, PhD \\ P.M. Carrillo BSc (Hons), MSc, PhD, FCIOB, MICE, CEng \\ C.J. Anumba BSc (Hons), PhD, CEng, FICE, FIStructE, FCIOB, MASCE \\ A.M. Al-Ghassani BEng, MSc, PhD, MASCE
}

Department of Civil and Building Engineering

Loughborough University

Loughborough

Leicestershire LE 11 3TU, UK

\section{Author for Correspondence}

Dr Patricia Carrillo

Department of Civil and Building Engineering, Loughborough University,

Loughborough, Leicestershire LE 11 3TU, UK

E-Mail: P.M.Carrillo@lboro.ac.uk

Phone: 01509222634

Fax: 01509223945 


\begin{abstract}
Performance management is a key issue in the construction industry as a result of complex internal and external factors. Large construction organisations are implementing performance management models to improve business processes, products and management of people to facilitate continuous improvement. This study investigates the implementation of performance management models in large construction engineering organisations. Firstly, a brief review of the drive for performance improvement and the strategic considerations for the adoption of performance management models is carried out with specific reference to the Balanced Scorecard and the EFQM Excellence Model. Secondly, using case studies of large construction engineering organisations, the findings from the implementation of performance management models are analysed and discussed. It is shown that whilst progress has been made in the implementation of performance management models in large construction organisations, significant challenges remained at the planning, deployment and assessment and review stages. This includes the motivation for performance management, leadership and resources, communication mechanisms, measurement and data collection techniques, and the role of knowledge management. Performance management models provide a basis to develop strategy for sustaining long-term business objectives, and more construction organisations will adopt such innovative tools to facilitate continuous improvement, as the business benefits become clear.
\end{abstract}

Keywords: Performance management models, EFQM Excellence Model, Balanced Scorecard, knowledge management, construction organisations 
Major construction industry review reports and recent initiatives have identified performance improvement as a key issue (Latham, 1994; Egan, 1998). The most recent review also recognised the need for continuous performance improvements but emphasises the role of innovation (Fairclough, 2002). Managing an organisation's performance is important for a number of reasons. This includes both internal and external factors such as the need to attract future investment, to retain and attract more customers, to remain competitive and innovative in order to increase profit and share prices. However, it is now recognised that traditional financial measures alone are no longer sufficient for understanding performance in a dynamic business environment, as it encourages short-termism leading to a lack of strategic focus and failure to provide data on quality (Kagioglou et al, 2001).

Recent initiatives such as the use of key performance indicators (KPIs) for construction are a reflection of the growing need to focus on a range of quality and performance issues such as client satisfaction, defects, health and safety, and productivity (Department of the Environment, Transport and the Regions, 2000). Adopting performance management models such as the EFQM Excellence Model (EFQM, 1999b) and the Balanced Scorecard (Kaplan and Norton, 1996) encourage organisations to respond to challenges with a forward-looking perspective focusing on a broad range of quality measures. Both models have been around for over 10 years but the take-up within construction is slow (Watson and Seng, 2001). 
The aim of this study is therefore to investigate the implementation of performance management models in large construction engineering organisations. The specific objectives are:

- To identify the drive and strategic considerations in the adoption of performance management models; and

- To critically evaluate the performance of large construction organisations in implementing performance management models

The first objective is addressed through a review of performance improvement with reference to the Balanced Scorecard and the EFQM Excellence Model. The second objective is addressed through in-depth case studies focusing on the implementation of performance management models in large construction engineering organisations.

Following this introduction, the research methodology is outlined in the next section. This is followed by a review of the drive and strategic aspects of performance management models which provides the basis for the case study investigation in the subsequent section. The paper concludes with an analysis and discussion of the key findings and lessons learnt from the case studies. 
The methodology adopted is based on a review of the literature and a case study approach. The literature review provided the platform for developing specific themes for the case study investigations. This included the motivation for performance management, choice of models and performance measures, knowledge management, which is central to innovation, and other factors associated with the implementation process. The case studies involved eight of the project's industrial partners which included four national and four international firms. Semi-structured interviews were conducted with senior and middle level managers involved in performance management who were asked to respond to questions from an organisational rather than a personal perspective. A total of 28 interviews were conducted, lasting from half an hour to two hours. This includes 14 interviews with business/continuous improvement managers, business development managers, quality mangers, - and another 14 interviews with others supporting performance management processes such as knowledge managers, financial directors and technical/group directors. Between 2 to 5 people were interviewed in each organisation with participants carefully chosen to ensure that all aspect of the case study investigations are addressed.

\section{DRIVE FOR PERFORMANCE IMPROVEMENT}

Approaches for improving business performance in the construction industry have evolved over the years from quality assurance to Total Quality Management (TQM). Quality assurance is reactive and 'inspection oriented'. Stitt (2002) noted that many construction organisations relying on quality assurance for business 
improvement have failed to achieve the desired impact and lasting change. TQM, on the other hand, is proactive and 'prevention oriented' by extending the quality concept to all aspects of an organisation, its people, resources, products, leadership to satisfy customers.

Construction organisations are beginning to recognise the need to focus on a range of quality measures such as product issues (e.g. defect rates, client satisfaction, society view), process issues (e.g. health and safety, procurement) and people issues (e.g. employee satisfaction, empowerment and involvement) to facilitate continuous improvement (Hoxley, 2000; Sinthawanarong, 2000 ). Sommerville and Robertson (2000) argued that 'an organisation adopting the principles of Total Quality Management quickly appreciates that financial measures on their own are very limited in reflecting the wider aspects of achievements and progress in general'. Learning and knowledge management is central to the TQM philosophy of continuous improvement (Love et al, 2000), and performance management models provide a framework for incorporating a range of quality measures to facilitate continuous improvement.

\section{PERFORMANCE MANAGEMENT CONSIDERATIONS}

There are several considerations in the implementation of performance management models - strategic planning, operationalisation and review. Strategic planning is a crucial part of performance management as it is important for the business objectives to be defined. Choosing an appropriate strategic framework to incorporate the business objectives of an organisation is therefore 
critical. The next stage involves operationalisation of the strategic plan by establishing a set of measures to assess corporate strategy and objectives necessary to monitor continuous performance improvement (Basu, 2001). Measurement is the information system at the heart of the performance management process (Kagioglou et al, 2001). The final stage requires a review of the results using the performance measures established to identify gaps, the implications for learning and knowledge management, and performance improvement initiatives to achieve key business results. A sequence for introducing a performance management model is shown below.

Insert Figure 1: Sequence for Performance Management Implementation

\subsection{Strategic Framework for Performance Management}

Strategic frameworks such as the Balanced Scorecard and the EFQM Excellence Model are good in incorporating quality into performance improvement and business strategy (Robinson, 1999, Butler et al, 1997). Both models show an explicit connection between quality principles and key performance measures.

\section{Balanced Scorecard}

Kaplan and Norton (1996) introduced the Balanced Scorecard (Figure 2) in recognition of the need to supplement traditional financial measures.

Insert Figure 2: The Balanced Scorecard 
Criteria from three additional perspectives - customers, internal business processes and learning and growth - are included to allow companies to track financial results while building capabilities to facilitate future growth. It allows managers to introduce four new processes for linking long-term strategic objectives with shortterm actions. The processes are:

- translating the vision to build a consensus around the organisation's vision and strategy.

- communicating and linking - facilitate communicating strategy up and down the organisation and linking it to departmental and individual objectives.

- business planning - enables companies to integrate business/ financial plans.

- feedback and learning - gives organisations the capacity to modify strategies for real-time learning.

\section{EFQM Excellence Model}

The EFQM Excellence Model (Figure 3) is developed by the European Foundation for Quality Management to sustain long term strategic objectives (EFQM, 1999a).

\section{Insert Figure 3: The EFQM Excellence Model}

At the heart of this approach is the 'excellence concept' defined as 'outstanding practice in managing the organisation and achieving results' (EFQM, 1999b). The model ensures a balance between the needs of all relevant stakeholders, and incorporates financial as well as leading indicators of future financial performance. It consist of the following key elements:

- a dynamic mechanism identifying the links between actions required (enablers) to achieve strategic objectives (results); 
- enabler criteria dealing with how the various activities are undertaken;

- $\quad$ results criteria focussing on what results are achieved; and

- linkages showing the role of learning and innovation in improving enablers which in turn influences the results.

Both the Balanced Scorecard and the EFQM Excellence Model address serious deficiency in traditional performance management built around financial measures. They provide a structured approach for identifying improvement opportunities and threats, and translating an organisation's vision to achievable goals, targets and specific tasks. They also provide a means for balancing short and long term strategic objectives, financial and non-financial measures, lagging and leading indicators, external and internal performance (CIRIA, 2001). A growing number of construction organisations are therefore adopting the Balanced Scorecard and the EFQM Excellence Model as strategic frameworks to respond to the changes taking place in the industry.

\subsection{Performance Measures}

It is important to choose a set of integrated measures relevant to an organisation's strategic objectives and key performance results (Butler et al, 1997). The Balanced Scorecard and the EFQM Excellence Model translates an organisation’s strategy into a comprehensive set of performance measures. These measures are required for setting targets, monitoring performance, benchmarking against industry performance and identifying improvement opportunities. Quality does not improve unless it is measured (Reicheld and Sasser, 1990). Measures should therefore be 
smart - specific, measurable, attainable, relevant and timely (Hampshire, 1999). Stewart (1997) argued that "if you cannot demonstrate the link between increased customer satisfaction and improved financial results, you are not measuring customer satisfaction correctly".

\subsection{Knowledge Management}

The purpose of measurement is to identify strengths and weaknesses i.e. areas for improvement in order to assess the implications for learning and knowledge management. Incorporating learning and knowledge management to inform the assessment and review stage is fundamental to the TQM philosophy of continuous improvement (Love et al, 2000). The Balanced Scorecard and the EFQM Excellence Model incorporate a learning and knowledge management dimension that facilitate incremental innovation. Table 1 shows different stages of innovation associated with the EFQM Excellence Model.

Insert Table 1 Innovation maturity stages. Source (EFQM, 1999)

At the maturity stage, organisations are regularly involved in innovation, as improvement activities become an integral part of the organisation's culture.

\section{CASE STUDIES}

This section outlines the implementation of performance management models in construction organisations. Eight case studies were conducted but only four are reported below for brevity. A profile of four cases that is representative and reflects 
a balance of two international and two national firms at different levels of maturity is given below. However, detailed discussions and conclusions that follows are drawn from the eight case studies.

\subsection{Case A}

This is an international company of about 4,000 employees with an annual turnover of over $£ 500$ million. It was recently acquired by a major utility company, which now forms part of the group. The company is involved in the full life cycle of constructed assets including ownership with business activities ranging from property development, construction of commercial buildings to heavy civil engineering projects.

The company has used its own performance management model since 1995. It is a hybrid model incorporating key features from the EFQM Excellence Model and the Balanced Scorecard. The model is used to determine what is important and to provide the basis for strategic improvement. The motivation for using a performance management model is to be 'the best in the UK construction industry' and a 'world class company'. Implementation of the model is the responsibility of a senior manager, supported by a co-ordinator, 4 full-time facilitators on secondment from business units, and 32 part-time facilitators with day jobs in various business units.

There are eighteen measures developed, including safety (which is considered important for a construction company) to reflect a balance between customers, 
people, processes and the financial aspects. However, some of the measures are still evolving. The company's key performance indicators (KPIs) were developed before the Egan (1998) recommendations. Data for the model are collected from business units, through internal surveys, and external surveys by independent consultants. The company recognised that all aspects of the model are important and are linked together. As one manager puts it ' One of the things you look for in assessment is the inter linkages'. 'Even though the model is prescribed as discrete boxes, they are not loose connections; each thing that is measured should have a strong linkage with other measures'. The model is implemented through facilitation rather than 'policing' adopted by traditional quality control departments. The company argued that the part-time facilitators have a better understanding of improvement issues relating to the business units they operate in. The result from the assessment is used to inform management about performance and provides the basis for developing improvement initiatives to become world class.

There is no explicit link between the company's performance management and knowledge management strategies. A Knowledge Manager has recently been appointed and a strategy is being developed. The business improvement strategy is more advanced than the knowledge management strategy but it is recognised that there is a need for better alignment or integration of knowledge management into business improvement.

\section{$\underline{5.2 \quad \text { Case B }}$}


This is a national, UK based company with over 1500 employees and an annual turnover of $£ 500$ million. The company's focus is on whole life construction and it is involved in a wide range of building and civil engineering projects.

The EFQM Excellence Model is used as the framework for driving continuous improvement. It has evolved since 1999 and has allowed TQM to be approached in a structured way. The Balanced Scorecard was explored briefly but subsequently abandoned, as most of its customers were thinking of, or are using the EFQM Excellence Model. The main motivation is the company's Chairman who passionately believes in the principle that 'if you don't measure it, you cannot manage it'. The other motivating factor is the need for a cultural change driven by clients. There is a business improvement manager to co-ordinate the strategy, supported by three staff and 24 part-time promoters. There is a budget for an external consultant retained to help in the implementation process.

Performance measures include project, commercial and business unit KPIs. It is recognised that all aspects of the EFQM Excellence Model are important as they are linked together. As part of the implementation, an employee's perception survey was carried out using the nine criteria of the model. The weighting of the different criteria of the model was used to arrive at an aggregate score. This result was used as a teaching tool to ensure that staff understood what the company is trying to achieve. The company is presently developing objectives and targets that will be cascaded downwards and ultimately measured. This is also as part of a drive to inform employees and business units about policy and strategy. Measures 
for partnership and resources, and other aspects of the model have also been developed. Most of the data are collected from the cost reporting system.

There are no explicit links between business improvement and knowledge management strategies but there are plans to address this. The responsibility for knowledge management has recently been given to the financial director as part of the company's effort to review its Intranet. The Continuous Improvement Manager has recently been asked to incorporate knowledge management into continuous improvement as the link is increasingly recognised as important.

A key enabler is the willingness, commitment and support of staff, despite their busy schedules, to participate in workshops and to discuss positively about how processes work in different parts of the business. A major constraint is time, as a methodical approach is required to take account of the long hours worked by some staff. There is also a cultural barrier associated with people's reluctance to be open and honest.

\section{$\underline{5.3 \quad \text { Case C }}$}

This is an international company with about 50,000 employees and an annual turnover of over $£ 4$ billion. It has recently been restructured following a high profile merger with a large international professional services group. The company's focus is on engineering design ranging from buildings to heavy civil engineering projects. 
The company has started to use the EFQM Excellence Model as a strategic framework for analysing business units, projects, teams etc. Prior to that, the Balanced Scorecard was explored but abandoned as it was argued that it is incorporated into the 'Results' side of the EFQM Excellence Model. The company's newly appointed Head of Continuous Improvement, previously the quality manager, argues that the motivation for implementing the model is externally driven by clients who are demanding it, and internally by people trained in strategic management.

The company uses a range of measures for projects and processes. However, it is recognised that it is 'important not to measure until you understand what you are trying to do'. Customer measures are considered crucial as 'you cannot separate the internal and external customers. It is argued that 'if you cannot satisfy your internal customers (i.e. employees), you have no chance of satisfying your external customers'. In terms of implementation, the key to success is recognising the holistic nature of the EFQM Excellence Model. Different parts of the organisation are at different levels of maturity and different approaches are used for each area of the business. Assessment is also conducted but the areas of improvement identified are considered more important than the scores. The benefits of the EFQM Excellence Model are assessed by top management involvement, acceptance from the business, and by setting deliverables and monitoring the improvement achieved using KPIs. 
There are no links between the performance management and knowledge management strategies. The appointment of a Chief Knowledge Officer (CKO) reflects the commitment of the company to knowledge management. However, the performance management strategy is only beginning to be recognised in one of the business units with very limited resources allocated for support. The KM strategy, on the other hand, is rolled out from a corporate angle, enjoying top management support and adequate resources.

The key barrier in using the model is 'getting people to understand that it is not just another initiative but if you don't adopt it as a way of doing business you will fail'. Other barriers include time and resources. It was recognised that one of the weaknesses of the model is 'its inability to deal with change' and argued that most businesses fail because they do not have a change management capability.

\section{$\underline{5.4 \quad \text { Case D }}$}

This is a national, UK based company employing 250 people with an annual turnover of over $£ 100$ million. They are involved in construction projects from design, construction to facilities management.

The company uses the EFQM Excellence Model as a framework for business performance management. The company is motivated because it believe that performance measurement adds benefit and improves profitability. The financial 
director is in charge of business improvement and is supported by a small team dealing with KPIs and the performance-monitoring system.

There are measures at different levels of the organisation - corporate and project level KPIs. The strategic plans drive the performance targets. In terms of elements of the EFQM Excellence Model, policy and strategy are considered crucial. Critical success factors are identified and measured to monitor improvement. For example, under customer and society aspects, the aim is to produce quality assets that are sustainable. Partnership and resources are also important, as there is a move away from competitive adversarial relationships to co-operative supply chain management. Performance indicators have also been developed for the selection and approval of supply chain members. Data is collected from different sources statutory books, head office, internal survey, site returns, monthly project managers' returns and financial review of projects.

Several barriers were identified; particularly the difficulties associated with convincing engineers with analytical minds, about some of the measures that are not tangible. As a result, 'smart' measures were introduced reflecting specific measurable things that people can recognise. Other barriers include creating bureaucracy, resistance to change and lack of understanding of the overall objective. The company recognises the need to appoint champions to address these barriers. 
There is currently no link between performance management and knowledge management but there are plans to have a formalised linkage. A knowledge management strategy is being formulated and there are 4 or 5 champions working on it, mainly on an ad hoc basis. The company has had to rely on the services of two consulting organisations as part of change management, one focussing on people aspects and the other on how knowledge is captured from processes.

\section{ANALYSIS AND DISCUSSION}

Table 2 below compares the four case study organisations with respect to key aspects of their business improvement strategy.

Insert Table 2: Comparison of performance management practices

Performance management is essential but a structured approach to implementation is vital for a successful improvement plan. This section discusses the experience of the organisations in implementing performance management models in terms of planning, deployment, and assessment and review.

\subsection{Planning}

\section{$\underline{\text { Motivation }}$}

All of the case study organisations except one have, or are fine-tuning their strategy for performance management and are motivated to do so for a variety of reasons. Some are internally driven whilst others are externally driven by clients, business partners or the agenda set by Egan (1998). This includes changing business practices to reflect what customers want, addressing problems associated with the 
supply chain, maintaining a competitive advantage or attempting to become a world class company.

\section{Choice of Model}

All the case study organisations, except the organisation with the hybrid model, are using the EFQM Excellence Model, although some have experimented, in varying degrees, with the Balanced Scorecard in the past. The growing popularity of the EFQM Excellence Model is due to a number of factors such as its holistic nature, client influence, robustness and clarity in understanding and linking enabling activities with results, and the relative ease of determining and monitoring associated indicators. Some of the case study organisations argue that it is a less structured/holistic tool considered to be only the 'Result side' of the EFQM Excellence Model.

\subsection{Operationalisation}

Performance management is implemented in different ways. Some organisations are implementing it as a company-wide strategy. Others are using a diagonal, horizontal or vertical approach, i.e. implementing it initially in parts or selected business units before being rolled out into the whole company. The advantage of starting in a business unit is that the benefits could be proved and resistance to change reduced before selling it to other business units. Implementing it diagonally provides the added advantage of reaching all levels with a limitation on the number 
of people involved. However, leadership and resources are crucial in the implementation process.

\section{Leadership and Resources}

Seven case study organisations appointed business improvement or quality managers to co-ordinate their efforts on performance management. Only one organisation delegated such responsibilities to the financial director. There are different levels of resources to support implementation including full-time and part-time staff, and in some cases special advocates - promoters or champions working mainly on an ad hoc basis. Some have an IT infrastructure to facilitate measurement and benchmarking but there is usually no separate budget except in cases where external consultants are involved.

\section{$\underline{\text { Performance Measures }}$}

The range of performance measures used varies as different aspects of quality are measured. Most organisations rely extensively on the KPIs which include measures such as time, cost, clients, and health and safety issues crucial for construction organisations. However, this is problematic as KPIs are mainly lagging indicators reflecting past performance. As one senior manager put it "these are mostly historical (backward looking) rather than proactive (forward looking)". Furthermore, the measures are often not integrated, nor do they adequately address long-term strategic objectives or 'soft' issues, which determines future performance. There are also difficulties in measuring certain criteria. Most organisations do not have adequate, measures for leadership, policy and strategy and society. Measures 
for processes create problems too. Three organisations have been involved in high profile merger and acquisition activities recently and, as a result, are undergoing a major restructuring of their business processes. The implication is that some organisations suffer from having too many different processes, which, in part, explains why most businesses lack rigorous performance measures for their processes (Hammer and Stanton, 1999).

\section{Communication and Co-ordinating Mechanisms}

Different techniques are used for co-ordination including workshops, working groups, local steering committees to report regularly on business improvement issues. Support is usually provided by promoters, and in some situations, champions appointed for specific critical success factors.

\section{Barriers}

Organisational culture and people are key barriers. People find change traumatic, and are often reluctant to give open and honest answers. Other key barriers identified included scepticism, time and lack of resources. The findings from the case studies are consistent with Watson and Seng (2001) who cited considerable resistance from staff in regard to documentation gathering and implementation, and insufficient funds and time as major problems encountered, even though senior management provided full support and sufficient authority. Creating bureaucracy, lack of understanding, commitment, and lack of tangible measures are also key problems, so are the conflicts between day jobs and business improvement activities, difficulties in convincing senior management about the benefits. A 
change management programme should therefore accompany the implementation process to address such barriers.

\subsection{Assessment and Review}

\section{Measurement Process}

The purpose of measurement is to identify areas for improvement.

Assessment techniques range from less rigorous, opinion-based, often qualitative approaches to highly rigorous, quantitative, evidence-based approaches. The assessment techniques used by most organisations are not rigorous and there is generally less emphasis on scoring. It is more important for scoring to be based on trend rather than absolute values. External assessors were used by a few organisations to give credibility to their scoring process. Support from external advisors, consultants or externally trained internal assessors are important in choosing appropriate assessment techniques.

\section{$\underline{\text { Data Collection }}$}

A variety of sources are used to collect data such as internal surveys, project review or closure reports, site returns, head office, statutory books and external surveys by independent consultants. Some organisations share information on performance measures whilst others do not, and therefore find it difficult to benchmark particularly against world class companies in other business sectors. The creation of a number of benchmarking clubs in construction could facilitate learning and sharing best practice information on performance, consistent with 
what Bennett (2000) referred to as the 'third way' in construction, i.e the need to balance co-operation with competition.

\section{$\underline{\text { Knowledge Management Aspect }}$}

Three organisations have a knowledge management strategy, one is fine-tuning its strategy, whilst the rest are planning to have one in the short term.

However, the links between performance and the knowledge aspects of the models are often ignored or not properly exploited. Performance management should be underpinned by a learning culture and knowledge management strategy to enhance an organisation's ability to continuously improve its business performance, and more importantly, to keep abreast of innovation in processes, products and technology.

\section{$\underline{\text { Progress }}$}

Figure 3 shows the position of the case study organisations in terms of their progress in implementing performance management models. Their progress in implementing their knowledge management strategies is also shown. The zones on the horizontal axis reflect the different levels of maturity from 1 (low) to 5 (high) for performance management. The white ovals indicate ratings based on the interviewees' perception of the current positions of their companies. The black ovals show the research team's objective assessment of the relative positions following the case studies.

Insert Figure 4: Maturity Levels of case study organisations 
The researchers' ratings are based on an analysis of the key attributes in the case studies based on the process sequence for implementing performance management models - their approach, deployment and assessment and review mechanisms. A summary of some of the attributes is shown in table 2. Similarly, progress in terms of knowledge management implementation was assessed based on the STEPS maturity roadmap developed by Robinson et al, (2004).

The assessment shows that most organisations have over-estimated their levels of maturity. Only one international organisation (A) has made reasonably good progress in implementing performance management. The remaining organisations have made slow progress and are all in maturity zones 1 and 2. Although Case D has only recently adopted a performance management model, compared to Cases B and C, they are rated slightly ahead in terms of maturity. This is due to a number of reasons. The delegation of responsibilities for performance management to the Financial Director in Case D reflects the seriousness in raising the profile of nonfinancial measures and integrating them with traditional financial measures. Both Cases B and C (C with more experienced leadership) have being experimenting with performance management for a slightly longer period but implementation is mainly ad hoc. These findings confirm that most of the case study organisations are at the infancy stages in implementing performance management systems.

With respect to progress on the implementation of knowledge management, two of the cases reported ( $\mathrm{A}$ and $\mathrm{C}$ ) as well as cases $\mathrm{E}$ and $\mathrm{H}$ in the higher maturity zones are international companies. These findings are not surprising given that there is a 
greater need and urgency for larger international organisations to implement knowledge management systems as they have a significant amount of knowledge that is more diverse and geographically dispersed to manage.

\section{CONCLUSION}

The paper raises awareness of the key issues driving performance improvement and the problems of implementing performance management models in large construction engineering organisations. Whilst the case studies shows that progress have been made and it is important to follow a clear structure in implementing performance management models, significant challenges remain. It is therefore crucial to identify challenging issues at each stage of the process to improve implementation performance. For example, at the strategic stage, it is important to choose an appropriate framework with dimensions that reflects an organisation's motivation and objectives for implementing performance management. Leadership and resources, communicating mechanisms, performance measures and barriers need to be addressed at the operationalisation stage. Similarly at the assessment and review stage, measurement process, data collection and knowledge management are issues crucial to the development of an improvement plan.

Adopting performance management models could help construction organisations to: (1) develop a coherent approach to respond to the changes taking place in their organisations and the industry, (2) support continuous improvement in delivering 
products and services, and (3) appreciate the role of learning and knowledge management in the exploration of innovative solutions to maintain a competitive advantage. It is expected that more construction organisations will adopt performance management models as a way of doing business if the benefits are demonstrated. The findings should be of interest to researchers and practitioners as it highlights the state of performance management implementation in construction engineering organisations and the key issues to be addressed.

\section{ACKNOWLEDGEMENT}

This research is sponsored by the Engineering and Physical Sciences Research Council (EPSRC)- Grant No. GR/N01330. The contributions of a number of industrial collaborators to the project are acknowledged. 


\section{REFERENCES}

Basu, R. (2001), New Criteria for Performance Management: A Transition from Enterprise to Collaborative Supply Chain, Measuring Business Excellence, 5, 4, $7-12$.

Bennett, J. (2000), Construction - The Third Way, Managing Cooperation and Competition in Construction, Butterworth-Heinemann Ltd, Oxford

Butler, A., Letza, S.R. and Neale, B. (1997), Linking the Balanced Scorecard to Strategy, Long Range Planning, Vol. 30, No 2, 242 -253.

Department of the Environment, Transport and the Regions (2000), KPI Report for the Ministry for Construction, The KPI Working Group, London, U.K

CIRIA (2001), The Balanced Scorecard - The American Way, Members Report E1121, Report of a joint workshop with the British Quality Foundation held at the Commonwealth Institute, London

Eccles, R. G. (1991), The Performance Measurement Manifesto, Harvard Business Review, January - February, 131-137.

EFQM (1999a), Aspects of Excellence: European Quality Award Report, European Foundation for Quality management Brussels, Belgium 
EFQM (1999b), Eight Essentials of Excellence: The Fundamental Concepts and their Benefits, European Foundation for Quality management, Brussels, Belgium

Egan, J. (1998), Rethinking Construction: Report of the Construction Task Force on the Scope for Improving the Quality and Efficiency of the UK Construction Industry, Department of the Environment, Transport and the Regions, London Egbu, C. (2000), The Role of Tacit and Explicit Knowledge in Improving Organisational Innovations in Architecture, Engineering and Construction, Joint Meeting of CIB W55/W65 and TG31/TG35, Reading, UK, 15 September.

Fairclough, J. (2002) "Rethinking Construction Innovation and Research: A review of Government R \& D Policies and Practices, Department for Transport and Local Government Regions (DTLR), London, U.K

Hammer, M. and Stanton, S. (1999), How Process Enterprises Really Work, Harvard Business Review, November-December, 108-116.

Hampshire, J. (1999), The Logical Framework Approach Guidelines, Material prepared as part of AusAid's Project Management Guidelines.

Hoxley, M. (2000), Measuring UK Construction Professional Service Quality: The What, How, When and Who, International Journal of Quality and Reliability Management, Vol. 17, Nos. 4/5, 511-526.

Kagioglou, M., Cooper, R., Aouad, G. (2001), Performance Management in Construction: A Conceptual Framework, Construction Management and Economics, 19, 85-95

Kaplan, R.S. and Norton, D. P. (1996), The Balanced Scorecard - Measures that Drive Performance, Harvard Business Review, 70(1), 71-79. 
Latham, M. (1994), Constructing the Team, Joint Review of Procurement and Contractual Arrangements in the UK Construction Industry, London

Love, P.E.D, Li, H., Irani, Z., and Holt, G.D (2000), Rethinking TQM: Toward a framework for facilitating learning and change in construction organisations. The TQM Magazine, Vol. 12, Number 2.

Marquis, D.G. (1988), The Anatomy of Successful Innovations. In Tushman, M.L and Moore, W.L (Eds) Readings in the Management of Innovation, HarperCollins, New York, USA.

Reichheld, F.F. and Sasser (Jnr), W.E. (1990), Zero Defections: Quality Comes to Services, Harvard Business Review, September-October, 105-111

Robinson, H.S., Anumba, C.J., Carrillo, P.M., and Al-Ghassani, A.M. (2004). "STEPS: A Knowledge Management Maturity Roadmap for Corporate Sustainability", Special Issue on Managing Business Processes for Corporate Sustainability” Business Process Management Journal. (Accepted)

Robinson, L (1999) "Scorekeepers to Business Partners: Repositioning the Finance Function, Total Quality Management, Vol. 10, Nos 4 \& 5, S690-S696.

Sinthawanarong, K. (2000), Measuring Construction Performance Using a Comprehensive Approach, Proceedings of CIT 2000, Reykjavik, Iceland, 28-30 June, Gudnason, G. (ed.), 852-862.

Sommerville, J. and Robertson, H.W. (2000), A Scorecard Approach to Benchmarking for Total Quality Construction, International Journal of Quality and Reliability Management, Vol. 17, Nos. 4/5, 453-466.

Stewart, T.A. (1997), Intellectual Capital: The New Wealth of Organisations, Doubleday Dell Publishing Group, New York 
Stitt, D. (2002), Rethinking Quality, Construction Information Quarterly,

Construction Paper 151, Vol. 4, Issue 4, 11-14

Watson, P. and Seng, L.T (2001), Implementing the European Foundation for Quality Management Model in Construction, Construction Information Quarterly, Construction Paper 130, 1-8. 
Table 1 Innovation maturity stages.

\begin{tabular}{|l|l|}
\hline \multicolumn{1}{|c|}{ Innovation Status } & \multicolumn{1}{c|}{ Characteristics } \\
\hline Start up stage & improvement opportunities are identified and acted on \\
\hline On-the-way stage & continuous improvement is an accepted objective for every individual \\
\hline Mature stage & successful innovation and improvement is widespread and integrated \\
\hline
\end{tabular}

Source: Compiled from EFQM, 1999b 
Table 2: Comparison of performance management practices

\begin{tabular}{|c|c|c|c|c|}
\hline & Org. A & Org. B & Org. C & Org. D \\
\hline Geographical focus & International & National UK-based & International & National UK-based \\
\hline Motivation & $\begin{array}{l}\text { To be the best in UK } \\
\text { construction and a world } \\
\text { class company }\end{array}$ & $\begin{array}{l}\text { Company chairman } \\
\text { Most customers using } \\
\text { EM }\end{array}$ & $\begin{array}{l}\text { Clients demand } \\
\text { Staff trained in } \\
\text { strategic } \\
\text { management }\end{array}$ & $\begin{array}{l}\text { Performance } \\
\text { measurement adds } \\
\text { benefits }\end{array}$ \\
\hline Model Adopted & $\begin{array}{l}\text { Own Model } \\
\text { incorporating features of } \\
\text { EM and BSC }\end{array}$ & $\begin{array}{l}\text { EFQM Excellence } \\
\text { Model } \\
\text { Experimented with } \\
\text { BSC }\end{array}$ & $\begin{array}{l}\text { EFQM Excellence } \\
\text { Model } \\
\text { Experimented with } \\
\text { BSC }\end{array}$ & $\begin{array}{l}\text { EFQM Excellence } \\
\text { Model }\end{array}$ \\
\hline Implementation focus & Company-wide & $\begin{array}{l}\text { Initially in parts of } \\
\text { company }\end{array}$ & Business units & Company-wide \\
\hline Implementation date & 1995 & 1999 & 1999 & 2000 \\
\hline Leadership & Quality College Manager & $\begin{array}{l}\text { Continuous } \\
\text { Improvement Manager }\end{array}$ & $\begin{array}{l}\text { Head of Continuous } \\
\text { Improvement }\end{array}$ & Financial Director \\
\hline Resources & $\begin{array}{l}6 \text { full-time } \\
\text { including } 4 \text { on } \\
\text { secondment from } \\
\text { business units }\end{array}$ & $\begin{array}{l}4 \text { full-time } \\
24 \text { part-time/ ad hoc }\end{array}$ & $\begin{array}{l}1 \text { full-time but } 2 \\
\text { required for the } \\
\text { understanding phase }\end{array}$ & $\begin{array}{l}\text { Small team and } \\
\text { Dashboard co- } \\
\text { ordinators }\end{array}$ \\
\hline $\begin{array}{l}\text { Communication and } \\
\text { co-ordinating } \\
\text { mechanisms }\end{array}$ & $\begin{array}{l}\text { Workshops } \\
\text { Task teams }\end{array}$ & $\begin{array}{l}\text { Steering committees } \\
\text { Workshops }\end{array}$ & Workshops & Champions \\
\hline Data sources & $\begin{array}{l}\text { Employee surveys } \\
\text { Customer surveys } \\
\text { Other areas of company }\end{array}$ & $\begin{array}{l}\text { Projects reviews } \\
\text { Cost reporting system } \\
\text { Customer review } \\
\text { information }\end{array}$ & Business areas & $\begin{array}{l}\text { Site returns } \\
\text { Project reviews } \\
\text { Internal survey } \\
\text { Head office } \\
\text { Statutory books }\end{array}$ \\
\hline Assessment & $\begin{array}{l}\text { Benchmark externally } \\
\text { Internally with } 20 \\
\text { business units }\end{array}$ & $\begin{array}{l}\text { Employees perception } \\
\text { survey }\end{array}$ & $\begin{array}{l}\text { Surveys (internal } \\
\text { satisfying external } \\
\text { customers) }\end{array}$ & Surveys \\
\hline $\begin{array}{l}\text { Links with knowledge } \\
\text { management }\end{array}$ & No & No & No & No \\
\hline
\end{tabular}




\section{FIGURES}

Figure 1: Sequence in Performance Management Implementation

\begin{tabular}{|c|}
\hline \multicolumn{1}{|c|}{ Planning Stage } \\
Choose framework to incorporate \\
strategic objectives
\end{tabular}




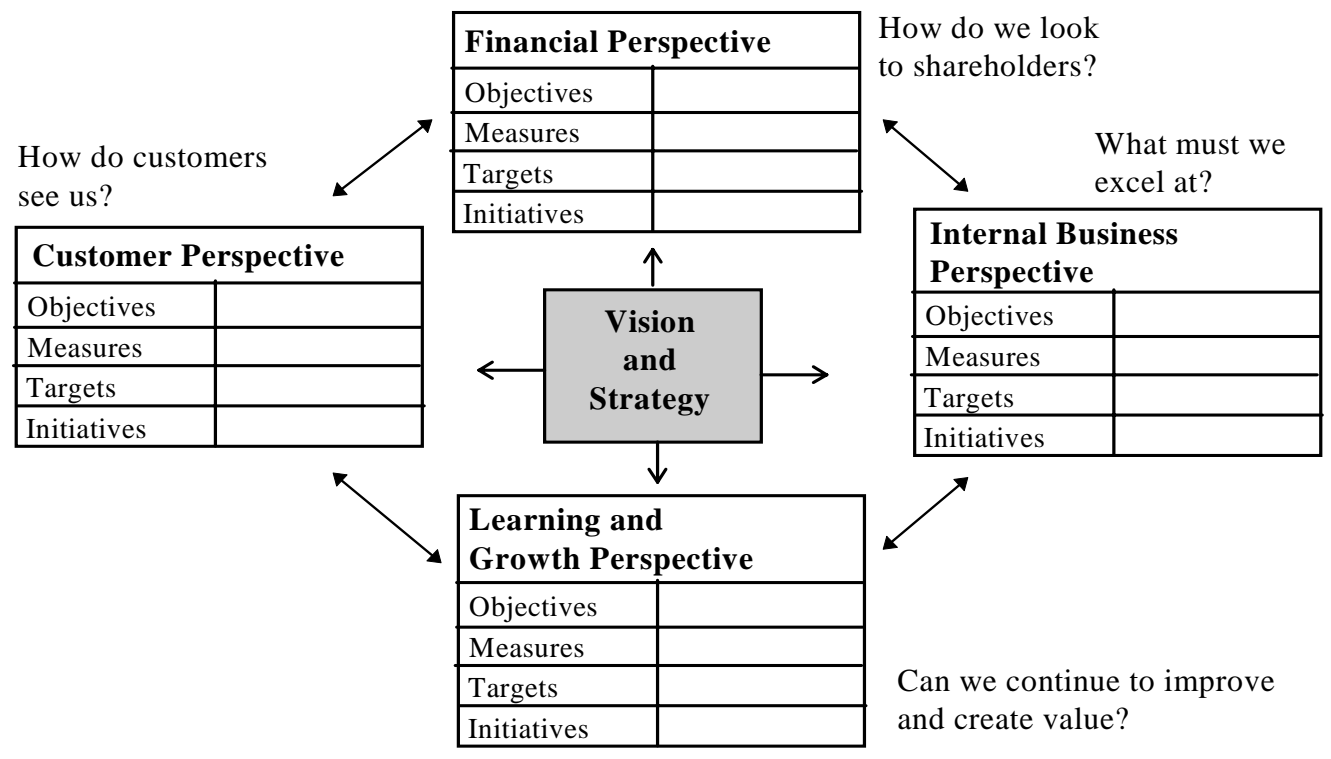

Figure 2: The Balanced Scorecard (Source: Kaplan and Norton, 1996) 


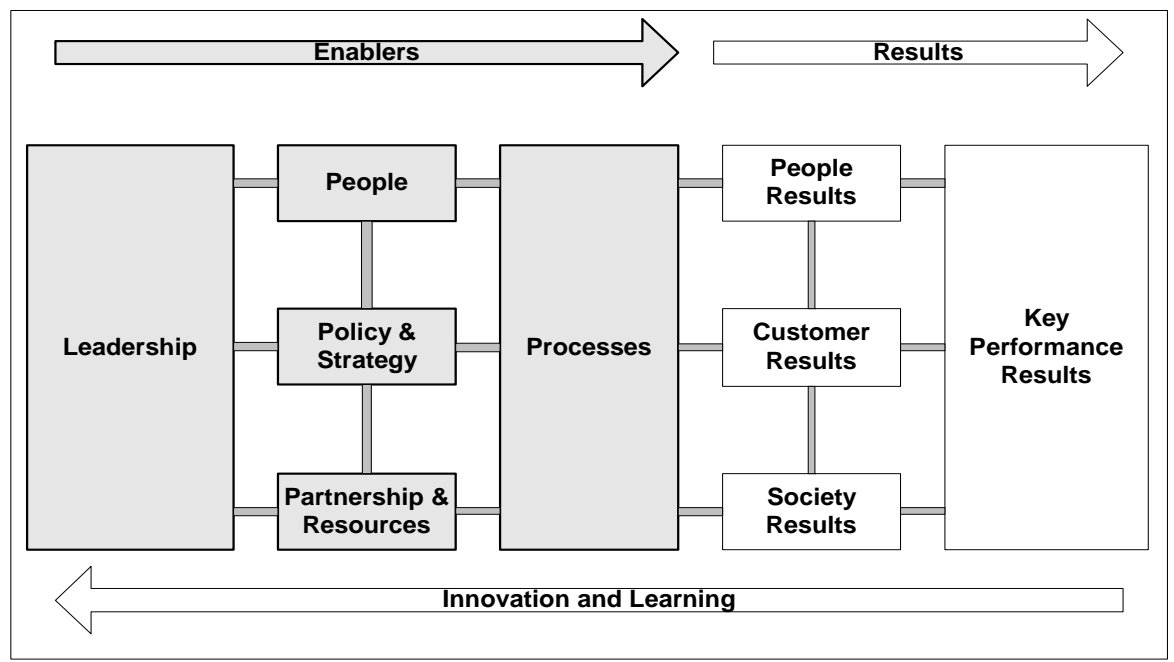

Figure 3: The EFQM Excellence Model (Copyright @ EFQM 1999-2003) 
Figure 4: Maturity Levels of case study organisations

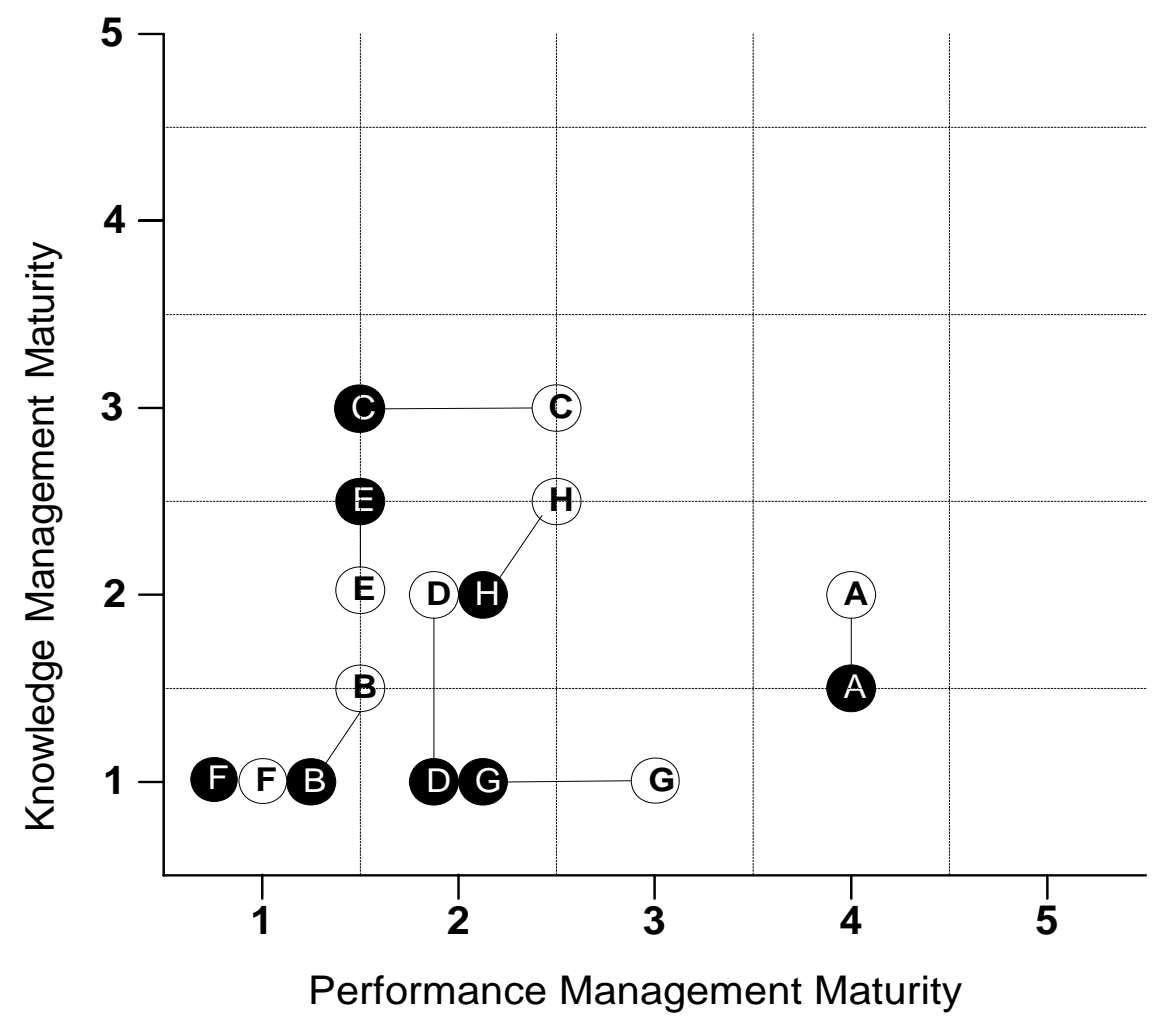

